\title{
The diachrony of the cognate object construction in Romanian and Hungarian ${ }^{\dagger}$
}

\author{
Imola-Ágnes Farkas ${ }^{\star}$ \\ Faculty of Letters, "Babeș-Bolyai" University, Str. Horea 31, 400202 Cluj-Napoca, Romania
}

\begin{abstract}
Article info
History:

Received November 12, 2020

Accepted December 4, 2020

Published December 27, 2020

Key words:

diachrony

cognate object construction

Romanian

Hungarian

Abstract

Building on the cross-linguistic observation generally valid in the majority of languages according to which cognate object constructions are frequently subject to diachronic changes, this paper provides an analysis of the history of diachronic changes in the cognate constructions of two typologically unrelated languages. We demonstrate that, although the present stage of Romanian and Hungarian lacks the canonical (aspectual) cognate object construction illustrated in to sleep a sound sleep, this structure does exist in both languages but either at an earlier language stage (the case of Romanian) or at the present language stage, as a result of a clear increase in it towards the modern period, but the cognate nominal is expressed by a pseudo-object (the case of Hungarian). Consequently, the diachronic change in these constructions of these languages is in two different directions.
\end{abstract}

\section{Introduction}

Building on the cross-linguistic observation generally valid in the majority of languages according to which cognate objects (COs) and cognate object constructions (COCs) are frequently subject to diachronic changes (see Horrocks \& Stavrou, 2010 or Lavidas, 2013b for (Ancient) Greek; Mittwoch, 1998 for Hebrew; Visser, 1963, Lavidas, 2013a, 2018 or van Gelderen, 2018 for English), this article offers an account of language change in these objects and these constructions in the history of Romanian and Hungarian. While it examines and compares the changes affecting them, the paper shows that these constructions in the two typologically unrelated languages have undergone diachronic change in two different directions: whereas the former language is characterized by a loss of the COC, the latter one is characterized by an increased use of the (especially aspectual) COC.

A COC is a construction where a verb takes an object expressed by a DP, the head noun of which is a nominalization of the verb stem. To put it differently, in such a structure the $\mathrm{CO}$ is both semantically and morphologically related to the verb as it is derived from (i.e., cognate to) it. We use the terms 'cognate object' and 'cognate object construction' in the narrowest sense; therefore, we only consider those canonical examples where the object is a semantic and morphological copy of the verb, and the $\mathrm{CO}$ is expressed by a DP/NP, cf. (1). Consequently, sentences such as the ones in (2)-where the object is only semantically related to the verb (2a) or the CO is expressed by a PP (adjunct) (2b) -will not be taken into consideration:

\footnotetext{
${ }^{\dagger}$ An earlier version and different parts of this paper were presented at the following conferences: Investigations into Romanian and European Biblical Traditions 9 ("Alexandru Ioan Cuza" University, Romania, May 2019), Nyelvelmélet és diakrónia 4 (Pázmány Péter Catholic University, Hungary, November 2019), The 19 International Conference of the Department of Linguistics (University of Bucharest, Romania, November 2019) and Variation and Change in the Verb Phrase (University of Oslo, Norway, December 2019). We thank the conference participants for their questions and suggestions, and the anonymous reviewers of the journal "Diacronia" for the observations. Part of this research was funded by Domus Hungarica Scientiarum et Artium, Hungarian Academy of Sciences.

^Email address: farkas_imola_agnes@yahoo.com.
} 
(1) Mary slept a sound sleep.

(2) a. Mary slept a fitful slumber.

b. they rejoiced with exceeding great joy (KJv, Matt, 2, 10)

According to their most recent classification (see Horrocks \& Stavrou, 2010; Lavidas, 2013a,b, 2014, 2018), these constructions are of three types. First, a transitive COC is built on a prototypical transitive verb, which selects a subject and obligatorily an object as well as in to do deeds. This object can be either a (singular/plural) regular direct object or a cognate object, which has a concrete meaning and can freely be passivized. Second, a transitivizing COC is built on a derived unergative verb of (re-)creation or consumption, which takes a subject and, optionally, an object as well, which can be a cognate or a non-cognate object (e.g. synonym or hyponym) as in to sing a song/an anthem. These cognate nominals are only accidentally morphological COs of the verb, they do not denote events, they are fully referential arguments, hence they do not share the properties of aspectual COs (see below); cf. Mittwoch (1998), Pereltsvaig (2002), de Swart (2007), Horrocks \& Stavrou (2010), and Lavidas (2013a). Third, an aspectual COC is built on a prototypical unergative verb, which requires only a subject and, exceptionally, can also take an accusative nominal, which is exclusively a cognate object as in to sleep a sound sleep. The most important features of these constructions and these objects are the following: the $\mathrm{CO}$ is not a referential or thematic object and cannot be treated as a subcategorized (internal) argument, hence it fails the canonical tests applying to subcategorized, referential and thematic objects (e.g. passivization, it-pronominalization, whquestioning or quantification with a strong determiner); it cannot be replaced by a similar noun such as a synonym or hyponym; and the main function of the entire construction is the expression of a limited event with beginning and end, hence the term 'aspectual'.

The present stage of the two languages investigated here lacks or severely restricts aspectual COCs as the exact counterpart of (1) is ungrammatical in both languages; $\mathrm{cf}$. (3a) and (3b):
a. *Maria a dormit o dormire profundă. Mary has slept a sleeping sound. 'Mary slept a sound sleep.'
b. *Mari aludt egy mély alvást. Mary slept a sound sleep.ACC 'Mary slept a sound sleep.'

Integrating both our previous work and new research, we show that both of these languages have the structure corresponding to (1) but either at an earlier language stage (the case of Romanian) or at the present language stage, as a result of a clear increase in this type of construction towards the modern period, but the $\mathrm{CO}$ is expressed by a pseudo-object (the case of Hungarian). Although our main interest is the subclass of aspectual COCs, we also discuss and illustrate transitive and transitivizing COCs from Biblical texts and everyday language.

Before digging deep into our analysis, let us make a remark concerning the comparative approach taken in this paper as one may wonder whether such a contrastive endeavour would be legitimate on diachronic grounds. As mentioned before, the two languages under investigation here are typologically unrelated and, to the best of our knowledge, there are no common models in their history that shaped their evolution and from which they would have developed into different directions as far as COCs are concerned. In addition, the main aim of this comparative analysis is not, first and foremost, to contribute to understanding Romanian as a foreign language by a native speaker of Hungarian (or vice versa) or to gaining insights into the complexity of Romanian through Hungarian (or vice versa). But the primary and intended purpose of the present analysis is mainly to contribute to the cross-linguistic observation concerning the diachronic changes of COCs, whereby Romanian is similar to (Ancient) Greek (Horrocks \& Stavrou, 2010; Lavidas, 2013b) and Hungarian is comparable to English (Visser, 1963; Lavidas, 2013a, 2018; van Gelderen, 2018). However, this similarity is not purely coincidental and is also mirrored, for 
instance, in the morphosyntactic properties of events of transition in these languages. As such, whereas Ancient Greek patterns with earlier stages of some Romance languages such as Old French and Old Catalan and they are all considered to be weak satellite-framed languages, which allow PathP to be realized as an element morphologically different from $v$; English is akin to Finno-Ugric languages such as Hungarian and they are more generally considered to be strong satellite-framed languages, which allow not only PathP but also (adjectival and particle) ResP to be realized as an element morphologically different from $v$ (Acedo-Matellán \& Mateu, 2013; Burnett \& Troberg, 2014; Acedo-Matellán, 2016 and Troberg \& Burnett, 2017).

The structure of the paper is as follows: Section 2 presents the diachrony of Romanian COCs. Section 3 focuses on the Hungarian data. Section 4 concludes.

\section{The diachrony of the COC in Romanian}

Modern Romanian has a small class of (transitive and mostly) transitivizing COCs in both Biblical texts, cf. (4), and everyday language, cf. (5), whereas aspectual COCs are extremely restricted in everyday speech, cf. (6a) and (6b), but may appear in poetry, cf. (6c); see also Creția (1956); Bejan (1972); Brâncuș \& Saramandu (1998); Avram (2001); Dimitriu (2002); Guruianu (2005); Hill \& Roberge (2006); Dragomirescu (2010, 2013); Dragomirescu \& Nicolae (2013); Pomian (2015), inter alia:

(4) a. și a suflat asupra lui suflare de viață (в.2001, Gen, 2,7) and has breathed onto him breath of life 'and he breathed onto him the breath of life'

b. amândoi am visat atunci câte un vis (в.2001, Gen, 41, 11) both of us have dreamed then each a dream 'and we each dreamed a dream'

(5) a. Copiii au cîntat cîntece frumoase. children have sung songs beautiful 'The children sang beautiful songs.'

b. Pacientul a băut această băutură pe stomacul gol. patient has drunk this drink on stomach empty 'The patient drank this drink on an empty stomach.'

(6) a. Ion a muncit o muncă grea. (Dragomirescu, 2013, p. 76) John has worked a work hard 'John worked hard.'

b. *Petru a oftat un oftat adînc. Peter has sighed a sigh deep 'Peter sighed a deep sigh.'

c. Și -am râs un râs de vagabond (BACOviA, p. 134) and have laughed a laugh of vagabond 'And I laughed a laugh of vagabond'

Present-day Romanian has mostly constructions where the object is only semantically related to the verb (see (7); cf. also Dragomirescu, 2010 or Dragomirescu \& Nicolae, 2013); the object is both morphologically and semantically related to the verb but it is nested into a PP adjunct, see (8), or the verb is a light verb, see (9):

(7) a. Maria a dormit un somn profund.

Mary has slept a sleep sound

'Mary slept a sound sleep.' 
b. Mihai a umblat o cale lungă.

Michael has strolled a way/path long

'Michael strolled a long distance.'
a. Maria a rîs cu un rîs isteric.
Mary has laughed with a laugh hysterical 'Mary laughed with a hysterical laugh.'
b. Părinții se bucură de bucuria copiilor. parents REFL rejoice of joy children.GEN
'Parents rejoice over their children's joy.'
(9) a. Petru a scos un oftat adînc.
Peter has let out a sigh deep
'Peter let out a deep sigh.'

b. Ion a făcut o plimbare/ o mărturisire.
John has made a walk $\quad$ a
'John took a walk/made a confession.'

In sharp contrast to this, Old Romanian has a wide variety of (aspectual) COCs, where the object is a semantic and morphological copy of the verb. More precisely, Romanian COCs are known to be extremely frequent in Old Romanian (OR), less frequent in Middle/Pre-Modern Romanian and very rare in Modern Romanian, where they are used especially in religious texts and popular speech; cf. Frâncu (2009); Dragomirescu (2010, 2013); Dragomirescu \& Nicolae (2013); Pană Dindelegan (2014, 2016), or Nicula Paraschiv \& Niculescu (2016).

The starting point for our diachronic analysis is the collection of OR texts established for The Syntax of Old Romanian (edited by G. Pană Dindelegan and published in 2016 by Oxford University Press), which contains both original texts and translations. Although some of them do not contain any COC that would correspond to the limitations imposed in this paper (see (2) above), most of them abound in these constructions ${ }^{1}$. The following examples serve to illustrate transitive, transitivizing $(10)$ and aspectual (11) COCs:

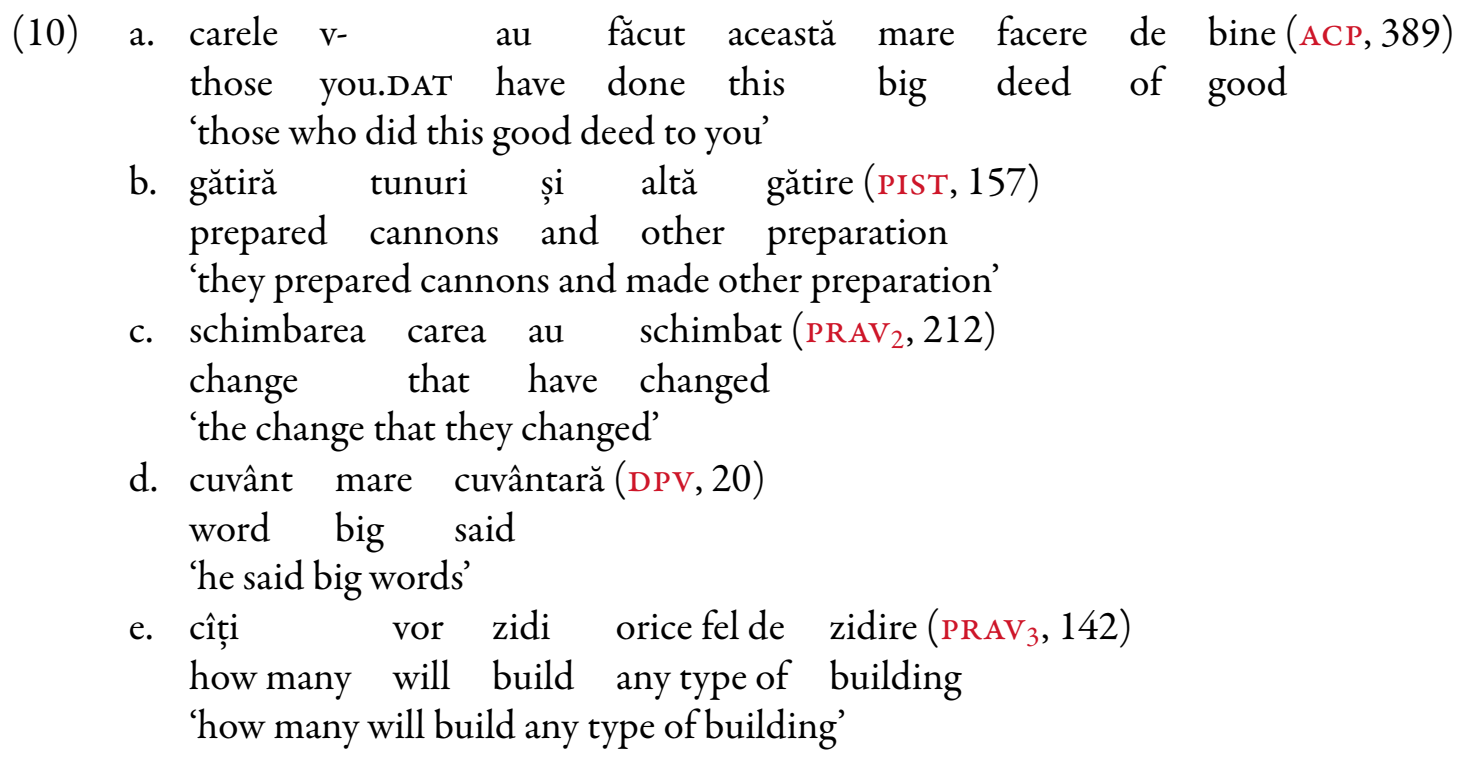

\footnotetext{
${ }^{1}$ Out of the 109 OR texts established for The Syntax of Old Romanian, so far we have selected and read 74 different texts representative for the two periods of OR and we have compiled a list of more than 200 verb-cognate object pairs. There are 19 texts which do not contain any COC that would conform to the above restriction but the remaining 55 texts-besides transitive, transitivizing and aspectual COCs—also have transitive constructions with two objects: a direct object denoting an animate entity (pre el 'him') and a cognate—also called secondary-object denoting an inanimate entity (plingere 'crying') as in Plînseră pre el plîngere mare 'they shed many tears for him'; see Pană Dindelegan (2014, 2016).
} 
f. mirosîm miros de mir scump (DVs, 79) smell smell of anointment expensive 'we smell the smell of expensive anointment'
a. dormire fără dormire să dormitedze $\left(\mathrm{CII}_{2}, 35\right)$
sleeping without sleeping CONJ sleep
'he should sleep a sleep without sleeping'
b. și de odihna voastră care odihneați (NîNv, 339) and of rest your that rest 'and of your rest that you take'
c. aceste umblete de demult le umbla (PIST, 171) these strolls of long time CL.3.FEM.PL strolled 'he had taken these strolls for a long time'
d. călătorește călătoriia ei $(\mathrm{AD}, 53)$ travels travelling his 'he travels his travelling'
e. toți aleargă o alergătură (Svi, 93) all run a running 'all run a run'
f. de va boli vreo boală a trupului copilul vostru (MăRG, 17) if will ail any sickness of body child your 'if your child has any sickness of the body'

In addition, it is not unusual in these texts that the referent of the $\mathrm{CO}$ is an (affected) animate entity and the DP object is accompanied by the differential object marker $p(r) e$; cf. the following example:

gîndește -te la bogați, pe care eu îi
think REFL at the rich whom I Clmbogățesc $(\mathrm{CD}, 34)$
'think of the rich that I make rich'

In the case of OR translated texts, the large number of these constructions can be explained by the influence of and the fidelity to the source language, as they copy the cognate structures occurring in the original Slavonic religious texts, which, in turn, are taken over literally from the Greek and Hebrew versions of the texts (Gamanovich, 2001; Arvinte, 2006; Pană Dindelegan, 2016; Nicula Paraschiv \& Niculescu, 2016). However, there are also original (that is, non-translated) - religious, literary or historical-texts in the corpus that contain a COC. Some relevant examples are given below:
a. greșit- au acesta greșală mare $(\mathrm{AD}, 107)$ mistake have this mistake big 'they made this big mistake'
b. sfat adevărat prietinesc au sfătuit $\left(\mathrm{CII}_{1}, 61\right)$ advice true friendly have advised 'they gave a truly friendly piece of advice'
c. poruncă să- i poruncească $\left(\mathrm{CII}_{2}, 108\right)$ order CONJ him order 'he should give him an order'
d. pe lîngă făgăduința ce- i făgăduise (ULM, 162) besides covenant that him covenanted 'besides the covenant that he made to him'
e. de acele amestecături, ce- 1 amestecasă (CLM, 112) of those mixtures that CL.3.M.SG mixed 'of those mixtures that he made'


Furthermore, it has been remarked that COCs in OR have a wider stylistic distribution (Pană Dindelegan, 2016), with a slight variation between the two periods: between 1521 and 1640 they are extremely frequent in diverse (but especially religious) texts, and between 1640 and 1780 they are less frequent and are slowly replaced by a verbal or nominal synonym/hyponym, or take on a light verb (Frâncu, 2009). In this respect, Farkas (2020c) takes a close look at the syntactic and semantic features of Romanian COCs in two different Bible translations: The Bucharest Bible, dated at 1688 (вв.1688), and The Bible from Blaj, dated at 1795 (в.1795), and confirms the direction of their change as already highlighted in the previous literature (see above). Considering the distinctions between the two (Greek) source texts these two Romanian translations have as a point of departure (i.e., the Septuagint published in Frankfurt in 1597 and the Septuagint published in Franeker in 1709), the study identifies the following techniques used in B.1795, which all aim to gradually reduce the redundancy between the verb and the CO: the introduction of a light verb (14), the introduction of a verbal synonym (15), the introduction of a noncognate object such as a hyponym (16), the replacement of the DP/NP object with a PP (adjunct) (17), and the omission of the $\mathrm{CO}(18)$ :
a. jîrtvuiră jîrtfă (Bв.1688) sacrificed sacrifice
b. au adus jertvă (B.1795, Jonah, 1, 15)
have brought sacrifice
'offered a sacrifice'
a. numi Adam numele (вв.1688)
named Adam name
b. au chemat Adam numele (B.1795, Gen, 3, 20)
have called Adam name
'Adam called (his wife's) name'
a. mîncare am să mănînc (Bв.1688)
food have coNJ eat
b. am a mânca bucatele (B.1795, John, 4, 32)
have to eat bites
'I have food to eat'
a. mă miraiu mirare (вв.1688)
REFL wondered wonder
b. $\mathrm{m}$-am mirat $\mathrm{cu}$ mirare (B.1795, Rev, 17, 6)
REFL have wondered with wonder
'I wondered with great wonder'
a. să ne îmbătăm beție (вв.1688)
CONJ REFL get drunk drunkenness
b. să ne îmbătăm (B.1795, Isa, 56, 12)
CONJ REFL get drunk
'we will fill ourselves with strong drink'

As for the last pair of examples, the note attached to this verse makes explicit reference to Bв.1688, with this particular verb-CO pair not existing in either of the two Greek source texts. Hence, there are (at least) two ways to render the above verse in (18a): either translate it with great fidelity to Bв.1688, or leave out the entire verse, with other previous translations already setting a precedent for this technique. Interestingly, B. 1795 relies on a third option by leaving out only the $\mathrm{CO}$, a case of justified omission as a translation strategy since it does not lead to an ambiguous or unclear sentence. Crucially, as the verb a se imbăta 'to get drunk' is a result verb (Rappaport Hovav \& Levin, 2010; Beavers \& Koontz-Garboden, 2020) or a telic, inherently change-of-state verb (Dragomirescu, 2010; Farkas, 2013), the result state is 
already encoded in the meaning of the verb, hence the CO only functions as an intensifier or emphasizer of this result state but its absence does not generate an incomplete or incoherent VP.

In sum, in this section we presented the diachrony of the COC in Romanian. We contributed to the relatively rich literature on this topic by completing it with the results of our research. In what follows, we turn to the diachrony of the cognate object construction in Hungarian and show that, at least as far as aspectual COCs are concerned, the direction of their evolution is opposite to that of the Romanian aspectual COCs.

\section{The diachrony of the COC in Hungarian}

In the same manner as modern Romanian, present-day Hungarian has a small class of transitive and transitivizing COCs both in Biblical texts (19) and in everyday language (20):
a. áldozzatok igaz áldozatokat $\left(s z J, P_{s}, 4,6\right)$ sacrifice true sacrifices.ACC 'offer the sacrifices of righteousness'
b. akkor énekelte Izrael ezt az éneket (szJ, Num, 21, 17) then sang Israel this.ACC the song.ACC 'then Israel sang this song'
a. A diákokkal megpályáztunk egy nagy pályázatot. the with students PRT.applied a big application.ACC 'We applied for a big grant with the students.'
b. Játszd a saját játékodat! play the own game.Poss.2sG.ACC 'Play your own game!'

In addition to the Biblical texts of Greek (Gianollo \& Lavidas, 2013), Hebrew (Mittwoch, 1998; Pereltsvaig, 2002; Horrocks \& Stavrou, 2010), Early Modern English (Lavidas, 2018) or Romanian (Teleoacă, 2012, 2013), Biblical Hungarian has transitive and transitivizing COCs, which are frequently associated with a stylistic choice and are claimed to have an emphatic function. They reflect the influence of and the fidelity to the source texts, as they take over the cognate structures occurring in the source (Greek or Hebrew) texts. Furthermore, in everyday speech the $\mathrm{CO}$ denoting a referential entity in a transitive or transitivizing COC can be accompanied by a verbal particle (20a) or appear as a definite and specific noun (i.e. with a definite determiner) (20b), and exhibits all the syntactic properties of a non-cognate thematic direct object (e.g. it can constitute the answer to a mit 'what.ACC' type of question).

But crucially, aspectual COCs are only found in diverse translations of the Holy Bible, see (21a), or in poetry, see (21b), as the everyday language blocks them almost completely, see (21c):

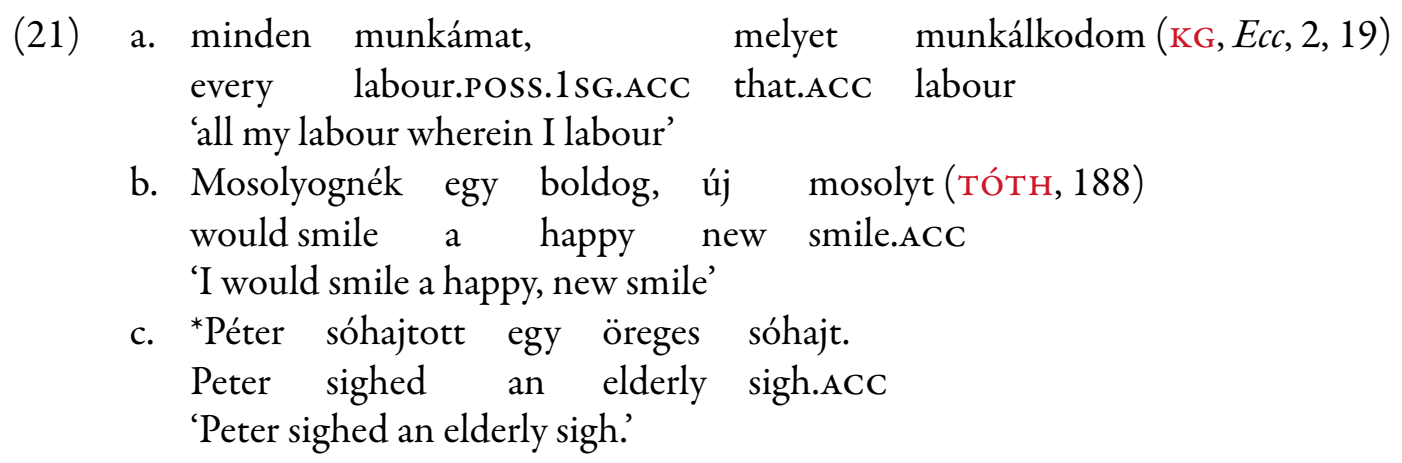

Instead, in the absence of aspectual COCs, where the object is literally cognate to the prototypical unergative verb it accompanies, Hungarian has accusative-marked $(-t)$ pseudo-objects (POs) (Piñón, 2001; 
É. Kiss, 2004; Kiefer, 2006; Csirmaz, 2008; Halm, 2012), that is, non-subcategorized, non-thematic and non-referential nominals, which take on the role of the aspectual $\mathrm{CO}$ in the language, as convincingly demonstrated and argued in Farkas (2019, 2020a). More precisely, these latter studies show that POs should be classified into three, where the motivation behind the following ternary division-instead of a binary one, which merges the POs of class (b) and (c) - is syntactically supported ${ }^{2}$.

a) the-very frequently used-PO with reduced lexical content egyet 'one/a(n).ACC'3;

b) a closed class of-frequently used-POs with more lexical content such as egy jót 'one/a good.ACC', egy nagyot 'one/a big.ACC', egy hatalmasat 'one/a huge.ACC' and egy óriásit 'one/a gigantic.ACC';

c) an open class of-less frequently used-POs with lexical content such as egy mélyet 'one/a sound.ACC', egy öregeset 'one/an elderly.ACC', egy széleset 'one/a wide.ACC', egy félelmeteset 'one/a dreadful.ACC', egy szelídet 'one/a tender.ACC', egy hangosat 'one/a loud.ACC', egy vidámat 'one/a joyful.ACC', egy gyorsat 'one/a quick.ACC', egy hirtelent 'one/a sudden.ACC', egy intenzivet 'one/an intensive.ACC', egy hosszút 'one/a long.ACC', egy bájosat 'one/a charming.ACC' or egy kellemeset 'one/a pleasant.ACC'.

Hence, the counterpart of the English canonical aspectual COC in (1) or the correspondent of (21c) are the sentences below:
a. Mari aludt egy mélyet.
Mary slept a sound.ACC
'Mary slept a sound sleep.'
b. Péter sóhajtott egy öregeset.
Peter sighed an elderly.ACC
'Peter sighed an elderly sigh.'

If we take a close look at different Bible translations in Hungarian, we notice that, towards the modern period, they display a strong tendency to drop the cognateness between the verb and the object, although this used to be a distinctive feature of these religious texts. The following two translations from the $20^{\text {th }}$ century, printed in 1908 (Károli Gáspár Revideált Biblia, KG), and in 1973, respectively (Szent István Társulati Biblia, SZIT), reveal the following techniques used in the latter version: the introduction of a light verb (23), the introduction of a verbal synonym (24), the introduction of a non-cognate object such as a hyponym (25), the omission of the verb (26) or the omission of the $\mathrm{CO}(27)$ :
a. fogad fogadást az Úrnak (KG) vows vow.ACC the Lord.DAT
b. fogadalmat tesz az Úrnak (szit, Num, 30,3) vow.ACC makes the Lord.DAT 'vows a vow unto the Lord'
a. álom amelyet álmodtál (KG) dream that.ACC dreamed
b. az álom, amit láttál (szit, Gen, 37, 10)
the dream that.ACC saw
'the dream that you dreamed'

\footnotetext{
${ }^{2}$ Although members of the three classes of POs exhibit uniform behaviour with respect to most cognate tests (e.g. passivization, quantification with a strong determiner, theta-role assignment, pronominalization, indefiniteness restriction, restrictive relative clause modification, mit 'what.ACC' type of questioning and aspectual contribution), they behave differently with respect to some other diagnostics (e.g. contrastive topicalization, focusing and adverbial interpretation).

${ }^{3}$ The PO egyet 'one.ACC' is formally the accusative-marked $(-t)$ numeral or indefinite article egy 'one/a(n)', with $-e-$ being the linking vowel on the stem ending with a consonant, in accordance with the vowel harmony characteristic of this language. Similar linking vowels $(-o-$ or $-a-)$ are found in all the accusative adjectives of class $(\mathrm{b})$ and $(\mathrm{c})$ that end in a consonant.
} 

a. semmi szőlőből csinált italt se igyék (KG) nothing from grape made drink.ACC not drink

b. nem szabad semmiféle szőlő levét sem innia (szit, Num, 6, 3) not allowed nosort of grape liquid.ACC neither drink.INF 'neither shall he drink any liquor of grapes'
a. Van nékem eledelem, a mit egyem (KG)
have I.DAT food.POss.1sG that.ACC eat
b. Van eledelem (szit, John, 4, 32)
have food.Poss.1sG
'I have food to eat'
a. nevezék nevét called name.POss.3sG.ACC Edom.DAT
b. elnevezték Edomnak (szit, Gen, 25, 30)
PRT.called Edom.DAT
'his name was called Edom'

More interestingly, Hungarian aspectual COs or, more precisely, POs fulfilling the function of the aspectual $\mathrm{CO}$ in the language, have been shown to be non-existent in Old Hungarian $(\mathrm{OH})$, rare in Middle Hungarian $(\mathrm{MiH})$, more increasingly frequent in Early Modern Hungarian (EMH) and extremely frequent and quite numerous in Modern Hungarian $(\mathrm{MH})$, where they are used both in everyday speech and in literary contexts; cf. Farkas (2020b). For the presentation of our diachronic analysis, we rely on the following three online corpora of the Research Institute for Linguistics of the Hungarian Academy of Sciences: $\mathrm{OH}$ corpus containing $\mathrm{OH}$ codices and miscellaneous minor texts (Ómagyar Korpusz, ÓK $)^{4}$; the database containing $\mathrm{OH}$ and $\mathrm{MiH}$ records and private correspondence (Történeti magánéleti korpusz, $\mathrm{TMK})^{5}$ and the New Hungarian historical database, a collection of diverse texts belonging to different genres and written in different styles in the EMH and MH periods (Új Magyar történeti szövegtár, MTSzt) ${ }^{6}$.

One striking, verb-related characteristic that a close corpus analysis can reveal is that more and more intransitive(ly) used verbs can take the PO egyet 'one.ACC' (or its variants eggyet, edjet, edgyet, egjet, egiet, eggiet, egyetis or édgyetis). In this sense, whereas only one single (semelfactive) verb and 12 different (semelfactive and activity) verbs take this PO in the ÓK corpus and in the diverse texts included in TMK, respectively, there is a significant increase in the verbs that take the same PO in the MTSzt texts. And this becomes evident if we compare the first versus the last decades of this latter period: whereas at the beginning of this period-more precisely, in the texts written between 1801 and 1850-there are fewer than 60 different instances of verbs that take this PO, at the end of the same period-more precisely in the texts written between 1951 and 2000-there are more than 200 different instances of verbs that co-occur with the same PO. The following examples are taken from TMK (28) and MTSzt (29):
a. egyet a jővő Tavaszra Disputáljok one.ACC the next on spring dispute
'I should have a dispute by next spring'
b. edgyet aluván föl édet nagy sirva one.ACC sleeping PRT woke big weeping 'after sleeping a sleep, he woke up weeping bitterly'
c. hát az uram eggyet sem szólhat well the husband.Poss.1sG one.ACC neither can utter 'well, my husband cannot utter a word'

\footnotetext{
${ }^{4}$ omagyarkorpusz.nytud.hu, see also Simon (2014) and Simon \& Sass (2012).

${ }^{5}$ tmk.nytud.hu, see also Dömötör et al. (2017) or Novák et al. (2018).

${ }^{6}$ clara.nytud.hu.
} 
(29) a. Ki mert legalábbis egyet sóhajtani? who dared at least one.ACC sigh.INF 'Who dared to sigh at least a sigh?'

b. néki is adjon eggyet inni belőle him also give one.ACC drink.INF from it 'he should also allow him to drink a little from it'

c. majd befordultam egyet alunni ismét then PRT.turned in one.ACC sleep.INF again 'then I turned in to get some sleep again'

d. hogy nevethessünk már egyet rajta so that can laugh already one.AcC on him 'so that we can finally have a laugh at him'

e. verekedtek egyet a rakparton fought one.ACC the on quay 'they had a fight on the quay'

f. úsztak egyet, majd lefeküdtek a füzfa mellé napozni swam one.ACC then PRT.lay the willow near sunbathe.INF 'they had a swim and then lay down near the willow to sunbathe'

Moreover, a careful examination of the occurrences of the above $\mathrm{PO}$ with reduced lexical content reveals a gradual numerical increase and frequency in use in it, with the number of this $\mathrm{PO}$ increasing dramatically by the MH period, where there is over twice as many egyet 'one.ACC' POs as in the EMH period'.

Similarly, the same gradual numerical increase and frequency of use is remarked in the case of the POs of class (b) and (c) as well, with the former registering their first occurrences in the EMH period, and the first-albeit still very rare-occurrences of the latter dating to the first half of the $19^{\text {th }}$ century. In a similar way to egyet 'one.ACC', the number of the few POs of class (b) is doubled by the MH period, where there are over twice as many egy jót 'one/a good.ACC', jókat 'good.PL.ACC' or egy nagyot 'one/a big.ACC', nagyokat 'big.PL.ACC' as in the EMH period.

The following examples taken from MTSzt show that POs of class (c) can occur either alone, see (30) or with another PO, see (31):
a. Ijedt föl Izidóra éleset sikoltva (1875) scared PRT Isadore sharp.ACC screaming 'Isadore woke up scarily, screaming a sharp scream'
a. Olyan keservest és nagyot sohajt (1867)
so painful.ACC and big.ACC sighs 'Peter Daniel sighed a painful sigh and scratched his head'
'he sighs such a painful and big sigh'
b. nedveset és boldogat ásítva (1952)
wet.ACC and happy.ACC yawning
'yawning a wet and happy yawn'

b. sóhajtott keserveset Péter Dániel, s megvakarta a fejét (1931) sighed painful.ACC Peter Daniel and PRT.scratched the head.POss.3sG.ACC

In sum, while the very frequently used PO egyet 'one.ACC' appears in the MiH period, POs of class (b) are first identified in diverse texts belonging to the EMH period and the first-albeit still very rareoccurrences of POs of class (c) date to the middle of the 19th century. In other words, the (beginning

\footnotetext{
${ }^{7}$ An important caveat is in order here: the above two observations are not unexpected or surprising considering that we deal with corpora of different length, with the number of written texts being doubled by the MH period. Still, the generalization remains that even if we focus only on the MTSzt texts, we have a general overview of the diachronic change and the direction of this change in the PO constructions of the language.
} 
of the) MH period is characterized not only by the emergence of POs of class (c) but, after a gradual numerical increase during the EMH period, also by a (very) high frequency in use of the PO of class (a) and, to a lesser degree, the POs of class (b).

In Romanian the high frequency of transitive, transitivizing and aspectual COCs in the OR period is ascribed to the fact that the texts containing this type of construction are mostly faithful translations of (Greek or Hebrew) religious texts but, as we have seen, these constructions gradually disappear by the Modern Romanian period. In sharp contrast to this, in Hungarian the emergence of (especially aspectual) COCs can be linked to the diachronic evolution of verbal (and telicizing) particles, which together contributed to the reduction of complex tense forms such as the past perfect illustrated in mondtam vala 'I had said' or the past imperfective illustrated in mondom vala 'I had been saying' (É. Kiss, 2008, 2017); cf Farkas (2020b).

\section{Conclusions}

The point of departure in this study was the observation that the exact counterpart of the canonical aspectual COC to sleep a sound sleep is ungrammatical at the present stage of Romanian and Hungarian. However, we have shown that both of these languages have the corresponding structure but either at an earlier language stage (the case of Romanian) or at the present language stage but the cognate nominal is expressed by a pseudo-object (the case of Hungarian). More importantly, we have cast light on the fact that these constructions diacronically change in the opposite direction: whereas Romanian is characterized by a gradual loss of the three types of COCs, Hungarian is characterized by an increased use of the aspectual COC, although Biblical Hungarian tends to gradually drop or replace parts of the transitive or transitivizing COC.

\section{Bibliography}

\section{A. Sources}

ACP = Ivireanul, A. (1714). Capete de poruncă, in Ștrempel, G. (coord.), Opere, Minerva, București, 1972, p. 386-394.

$\mathrm{AD}=$ Ivireanul, A. (1722-1725). Didahii, in Faifer, F. (coord.), Opere, Minerva, București, 1983.

B.1795 = Biblia de la Blaj. Biblia, adecă Dumnezeiasca Scriptură a legii vechi și a ceii noao, Blaj, 1795.

B.2001 = Biblia sau Sfânta Scriptură. Ediţie jubiliară a Sfântului Sinod/versiune diortosită după Septuaginta, redactată şi adnotată de Bartolomeu Valeriu Anania, Editura Institutului Biblic și de Misiune al Bisericii Ortodoxe Române, București, 2001.

Bacovia = Bacovia, G. (1930). Sepulcre violate, in Petroveanu, M., Botez, C. \& Simuț, I. (coord.), Opere, Editura Fundației Culturale Române, București, 1994.

Bв.1688 = Biblia 1688, in Arvinte, V., Caproșu, I., Gafton, Al., Manea, L. \& Ursu, N.A. 2 vol., Editura Universității „Alexandru Ioan Cuza", Iași, 2001, 2002.

CD = Cantemir, D. (1698). Divanul, in Cândea, V. (coord.), Editura pentru literatură, București, 1969.

$\mathrm{CII}_{1}=$ Cantemir, D. ( 1705). Istoria ieroglificăa, in Panaitescu, P.P. \& Verdeș, I. (coord.), Editura pentru literatură, București, 1965. Volumul I.

$\mathrm{CII}_{2}=$ Cantemir, D. ( 1705). Istoria ieroglifică, in Panaitescu, P.P. \& Verdeș, I. (coord.), Editura pentru literatură, București, 1965. Volumul II.

CLM = Costin, M. (1700-1750). Letopisețul Țării Moldovei, in Panaitescu, P.P. (coord.), Opere, Editura de Stat pentru Literatură și Artă, București, 1958, p. 41-201.

DPV = Dosoftei (1673). Psaltirea în versuri, Litera, Chișinău, 1998, p. 9-326.

DVs = Dosoftei (1682-1686). Viața și petreacerea svinților, in Frențiu, R. (coord.), Echinox, Cluj-Napoca, 2002.

KG = Károli Gáspár Revideált forditása (1908).

$\mathrm{KJV}=$ King James Bible (1611).

MĂRG = Mărgăritare. Cuvinte ale Sfintului Ioan Gură de Aur și ale multor Sfinți și Dascăli (1691), in Stuparu, F. (coord.), Cartea

Ortodoxă, București, 2010, p. 7-420.

NîNv = Învățăturile lui Neagoe Basarab către fiul său Teodosie ( 1700), in Moisil, F. \& Zamfirescu, D. (coord.), Minerva, București, 1970, p. 125-352.

PIST = Popescu, R. ( 1780). Istoriile domnilor Țării Românești, in Grecescu, C. (coord.), Editura Academiei, București, 1963, p. 3-302. 
$\operatorname{PRAV}_{2}=$ Indreptarea legii (1652), in Rădulescu, A. (coord.), Editura Academiei, București, 1962, p. 33-631.

$\operatorname{PRAV}_{3}=$ Pravilniceasca condică (1780), in Rădulescu, A. (coord.), Editura Academiei, București, 1957, p. $33-156$.

SZIT = Szent István Társulati Biblia (2003), Budapest.

szJ = Ó-és Újszövetségi Szentírás a Neovulgáta alapján (2007), Szent Jeromos Katolikus Bibliatársulat, Budapest.

SVI = Varlaam și Ioasaf ( 1670), in Stanciu Istrate, M. (coord.), Reflexe ale medievalității europene în cultura română veche:

Varlaam și Ioasafîn cea mai veche versiune a traducerii lui Udrişte Năsturel, Editura Muzeului Național al Literaturii Române,

București, 2013, p. 81-325.

тóтн = Tóth, Á. (1923). Azősök ritmusa, in Papp, Cs. (coord.), Tóth Árpád összegyüjtöttversei és versforditásai, Osiris, Budapest, 2006.

ULM = Ureche, G. ( 1725). Letopisețul Țării Moldovei, in Panaitescu, P.P. (coord.), Editura de Stat pentru Literatură și Artă, București,1958, p. 63-225. Ediția a II-a revăzută.

\section{B. References}

Acedo-Matellán, V. (2016). The Morphosyntax of Transitions. A Case Study in Latin and Other Languages, Oxford University Press, Oxford, Crossref.

Acedo-Matellán, V. \& Mateu, J. (2013). Satellite-framed Latin vs. verb-framed Romance: A syntactic approach, in "Probus", 25 (2), p. 227-265, Crossref.

Arvinte, V. (2006). Construcții perifrastice în Biblia de la București (1688), în ms. 45 și ms. 4389, in Arvinte, V. (coord.), Studii de istorie a limbii române, Editura Universităţii „Alexandru Ioan Cuza”, Iași, p. 180-184.

Avram, M. (2001). Gramatica pentru toți, $3^{\text {rd }}$ ed., Editura Humanitas, București.

Beavers, J. \& Koontz-Garboden, A. (2020). The Roots of Verbal Meaning, Oxford University Press, Oxford, Crossref.

Bejan, D. (1972). Relația internă frecventă în sintaxa limbii vechi, in "Studia Universitatis Babeș-Bolyai”, 17 (1), p. 93-99.

Brâncuș, G. \& Saramandu, M. (1998). Gramatica limbii române. Morfologia, vol. I, Atos, București.

Burnett, H. \& Troberg, M. (2014). On the Diachronic Semantics of Resultative Constructions in French, in Piñón, C. (coord.), Empirical Issues in Syntax and Semantics 10, p. 37-54, [online].

Csirmaz, A. (2008). Accusative Case and Aspect, in É. Kiss, K. (coord.), Event Structure and the Left Periphery, Springer, Dordrecht, p. 159-200, Crossref.

Creția, P. (1956). Complementul intern, in "Studii de gramatică", vol. I, Editura Academiei, București, p. 115-120.

Dimitriu, C. (2002). Tratat de gramatică a limbii române, 2. Sintaxa, Institutul European, Iași.

Dömötör, A., Gugán, K., Novák, A. \& Varga, M. (2017). Kiútkeresés a morfológiai labirintusból-korpuszépitésó-ésközépmagyar kori magánéleti szövegekböl, in "Nyelvtudományi Közlemények”, 113, p. 85-110, [online], Crossref.

Dragomirescu, A. (2010). Ergativitatea: tipologie, sintaxă, semantică, Editura Universității din București, București.

Dragomirescu, A. (2013). Intransitive verbs, in Pană Dindelegan, G. (coord.), The Grammar of Romanian, Oxford University Press, Oxford, p. 72-82.

Dragomirescu, A. \& Nicolae, A. (2013). L'objet interne en roumain: description, évolution et comparaison entre les langues romanes, in Casanova Herrero, E. \& Calvo Rigual, C. (coord.), Actas del XXVI Congreso Internacional de Lingüistica y de Filología Románicas, Walter de Gruyter, Berlin, p. 147-158, Crossref.

É. Kiss, K. (2004). Egy igekötöelmélet vázlata, in "Magyar Nyelv”, C (1), p. 15-42, [online].

É. Kiss, K. (2008). From the Grammaticalization of Viewpoint Aspect to the Grammaticalization of Situation Aspect, in É. Kiss, K. (coord.), Event Structure and the Left Periphery, Springer, Dordrecht, p. 129-157, Crossref.

É. Kiss, K. (2017). The rise and fall of Hungarian complex tenses, in Mathieu, E. \& Truswell, R. (coord.), Micro-change and Macro-change in Diachronic Syntax, Oxford University Press, Oxford, p. 61-74, Crossref.

Farkas, I-Á. (2013). Resultative Constructions in English and Romanian. A Comparative Analysis, Presa Universitară Clujeană, Cluj-Napoca.

Farkas, I-Á. (2019). Sóhajtott egyet, mélyet, hangosat: a magyar áltárgyak mint aspektuális belsö tárgyak, in "Nyelvtudományi Közlemények", 115, p. 173-198, Crossref.

Farkas, I-Á. (2020a). Atelic unaccusative verbs and cognate objects in Hungarian, in "Argumentum", 16, p. 95-114.

Farkas, I-Á. (2020b). Az egyet áltárgy diakróniájáról, in Balogné Bérces, K., Hegedűs, A. \& Pintér, L. (coord.), Nyelvelmélet és diakrónia 4, Elméleti Nyelvészeti Tanszék - Magyar Nyelvészeti Tanszék, Budapest - Piliscsaba, p. 87-113.

Farkas, I-Á. (2020c). Tradiție și inovație în Biblia de la București (1688) și Biblia de la Blaj (1795): Construcții cu complement intern, in "Studii și cercetări lingvistice", LXXI (2).

Frâncu, C. (2009). Gramatica limbii române vechi (1521-1780), Demiurg, Iași.

Gamanovich, A. (2001). Grammar of the Church Slavonic language, Holy Trinity Monastery, Jordanville, NY.

van Gelderen, E. (2018). The Diachrony of Verb Meaning. Aspect and Argument Structure, Routledge, London.

Gianollo, C. \& Lavidas, N. (2013). Cognate Adverbials and Case in the History of Greek, in "Studies in Greek Linguistics", 33, p. $61-75$.

Guruianu, V. (2005). Sintaxa textelor românești originale din secolul al XVI-lea. Sintaxa propoziţiei, Editura Universității din București, București. 
Halm, T. (2012). Unergative and/or Unaccusative: On the Argument Structure, Semantics and Syntax of Semelfactives in Hungarian, in Surányi, B. \& Varga, D. (coord.), Proceedings of the First Central European Conference in Linguistics for postgraduate students, Pázmány Péter Katolikus Egyetem, Budapest, p. 104-117.

Hill, V. \& Roberge, Y. (2006). A locally determined verb typology, in “Revue Roumaine de Linguistique”, LI (1), p. 5-22.

Horrocks, G. \& Stavrou, M. (2010). Morphological Aspect and the Function and Distribution of Cognate Objects across Languages, in Rappaport Hovav, M., Doron, E. \& Sichel, I. (coord.), Lexical Semantics, Syntax, and Event Structure, Oxford University Press, Oxford, p. 284-308, Crossref.

Kiefer, F. (2006). Aspektus és akcióminőség. Különös tekintettel a magyar nyelvre, Akadémiai Kiadó, Budapest.

Lavidas, N. (2013a). Null and cognate objects and changes in (in)transitivity. Evidence from the history of English, in "Acta Linguistica Hungarica”, 60 (1), p. 69-106, Crossref.

Lavidas, N. (2013b). Unaccusativity and the diachrony of null and cognate objects in Greek, in van Gelderen, E., Barðdal, J. \& Cennamo, M. (coord.), Argument Structure in Flux. The Naples-Capri Papers, John Benjamins, Amsterdam, p. 307-341, Crossref.

Lavidas, N. (2014). Cognate arguments and the Transitivity Requirement in the history of English, in "Lingua Posnaniensis", LVI (1), p. 41-59, Crossref.

Lavidas, N. (2018). Cognate noun constructions in Early Modern English. The case of Tyndale's New Testament, in Cuyckens, H., De Smet, H., Heyvaert, L. \& Maekelberghe, C. (coord.), Explorations in English Historical Syntax, John Benjamins, Amsterdam, p. 51-76, Crossref.

Mittwoch, A. (1998). Cognate Objects as Reflections of Davidsonian Event Arguments, in Rothstein, S. (coord.), Events and grammar, Kluwer, Dordrecht, p. 309-332, Crossref.

Nicula Paraschiv, I. \& Niculescu, D. (2016). Cognate objects and other pleonastic constructions, in Pană Dindelegan, G. (coord.), The Syntax of Old Romanian, Oxford University Press, Oxford, p. 605-611.

Novák, A., Gugán, K., Varga, M. \& Dömötör, A. (2018). Creation of an annotated corpus of Old and Middle Hungarian court records and private correspondence, in "Language Resources and Evaluation", 52, p. 1-28, Crossref.

Pană Dindelegan, G. (2014). Direct and secondary object ditransitive structures in Old Romanian, in "Linguistica Atlantica”, 33 (2), p. 25-37.

Pană Dindelegan, G. (2016). The secondary direct object, in Pană Dindelegan, G. (coord.), The Syntax of Old Romanian, Oxford University Press, Oxford, p. 143-149.

Pereltsvaig, A. (2002). Cognate objects in Modern and Biblical Hebrew, in Ouhalla, J. \& Shlonsky, U. (coord.), Themes in Arabic and Hebrew Syntax, Springer, Dordrecht, p. 106-136, Crossref

Piñón, C. (2001). Töprengtem egyet: azon, hogy mit jelent az egyet, in Bakró-Nagy, M., Bánréti, Z. \& É. Kiss, K. (coord.), Újabb tanulmányok a strukturális magyar nyelvtan és a nyelvtörténet köréböl, Osiris, Budapest, p. 182-198.

Pomian, I. (2015). Funcțiile sintactice „interne” - o certitudine?, in “Dacoromania”, XX (1), p. 83-94.

Rappaport Hovav, M. \& Levin, B. (2010). Reflections on Manner/Result Complementarity, in Rappaport Hovav, M., Doron, E. $\&$ Sichel, I. (coord.), Lexical Semantics, Syntax, and Event Structure, Oxford University Press, Oxford, p. 21-38, Crossref.

Simon, E. (2014). Corpus building from Old Hungarian codices, in É. Kiss, K. (coord.), The Evolution of Functional Left Peripheries in Hungarian Syntax, Oxford University Press, Oxford, p. 224-236.

Simon, E. \& Sass, B. (2012). Nyelvtechnológia és kulturális örökség, avagy korpuszépités ómagyar kódexekböl, in "Általános Nyelvészeti Tanulmányok", XXIV, p. 243-264.

de Swart, P. (2007). Cross-linguistic Variation in Object Marking, PhD dissertation, LOT Publications.

Teleoacă, D.-L. (2012). Particularități morfosintactice ale textului contemporan de rugăciune (II), in "Limba română”, XXII (34), p. 169-177.

Teleoacă, D.-L. (2013). Structuri poetico-retorice în textulpsalmic modern: construcții intensive și tautologice, in "Limba română", XXIII (7-8), p. 128-143.

Troberg, M. \& Burnett, H. (2017). From Latin to Modern French: A punctuated shift, in Mathieu, E. \& Truswell, R. (coord.), Micro-change and Macro-change in Diachronic Syntax, Oxford University Press, Oxford, p. 104-124, Crossref.

Visser, F. T. (1963). An historical syntax of the English language. Syntactical units with one verb, Brill. 